\title{
EKRANISASI NOVEL SURGA YANG TAK DIRINDUKAN KARYA ASMA NADIA KE FILM SURGA YANG TAK DIRINDUKANKARYA KUNTz AGUS
}

\author{
SIROJUL MUNIR', DANIA APRILIA ${ }^{2}$ \\ Universitas Galuh \\ Sirojulmunir518@gmail.com!, daniaaprilia21@gmail.com² \\ Pertama Diterima: 2I November 2020 \\ Bukti Akhir Diterima: 30 Desember 2020
}

\begin{abstract}
Abstrak
Ekranisasi merupkan istilah yang akhir-akhir ini semakin familiar dalam kajian sastra di Indonesia. Penelitian ini bertujuan untuk mendeskripsikan bentuk ekranisasi novel Surga yang Tak Dirindukan karya Asma Nadia menjadi film Surga yang Tak Dirindukan karya Sutradara Kuntz Agus. Metode yang digunakan dalam penelitian ini adalah metode penelitian deskriptif kualitatif. Metode analisis ini digunakan untuk menelaah isi dari suatu dokumen. Dokumen yang dimaksud adalah novel Surga yang Tak Dirindukan Karya Asma Nadia menjadi film Surga yang Tak Dirindukan Karya Sutradara Kuntz Agus. Berdasarkan hasil penelitian, novel Surga yang Tak Dirindukan karya Asma Nadia mengalami proses ekranisasi dari segi pengurangan, penambahan, dan perubahan variasi. Proses ekranisasi tersebut terdapat pada fungsi tokoh, latar, dan alur.Proses ekranisasi pada kategori aspek pengurangan, terdapat pengurangan 16 tokoh, 8 latar, dan 5 bagian alur, pada kategori aspek penambahan, terdapat penambahan 6 tokoh, 9 latar, dan 5 bagian alur, serta pada kategori aspek perubahan variasi, terdapat perubahan variasi 3 tokoh, 3 latar, dan 5 bagian alur.
\end{abstract}

Kata Kunci: ekranisasi, novelSurga yang Tak Dirindukan, filmSurga yang Tak Dirindukan

\begin{abstract}
Ekranisasi is a term that has recently become increasingly familiar in literary studies in Indonesia. This study aims to describe the form of ekranization of Asma Nadia's novel Heaven that is not missed by director Kuntz Agus' film Heaven that is not missed. The method used in this research is descriptive qualitative research method. This analysis method is used to examine the contents of a document. The document in question is that the novel Heaven That Asma Nadia Doesn't Miss A film is Heaven That Director Kuntz Agus Does Not Miss. Based on the research results, Asma Nadia's novel Heaven that is Not Missed underwent an ecranization process in terms of reduction, addition, and variation change. The ekranization process is contained in the function of the character, setting, and plot. The ekranization process in the subtraction aspect category, there was a reduction of 16 characters, 8 backgrounds, and 5 plot sections, in the addition aspect category, there were the addition of 6 characters, 9 backgrounds, and 5 plot sections, as well as in the variation change aspect category, there was a variation of 3 characters, 3 backdrops, and 5 groove sections.
\end{abstract}

Keywords: ekranisasi, the novel Heaven that is not missed, the film Heaven that is not missed

\section{PENDAHULUAN}

Perkembangan karya sastra Indonesia telah menunjukan peningkatan. Hal ini terlihat dari lahirnya berbagai ragam karya sastra. Keragaman karya sastra ini tentunya tidak terlepas dari peran seseorang di dalam kegiatan apresiasi sastra melalui berbagai penafsiran. Munculnya berbagai penafsiran dari apresiator dapat memberi peluang lahirnya sebuah karya sastra hasil transformasi. 
Transformasi adalah perubahan suatu hal atau keadaan (Nurgiyantoro, 2015). Transformasi karya sastra yaitu proses kreatif mengubah bentuk atau wahana karya dari karya sastra sebelumnya. Perubahan ini misalnya, mengubah puisi menjadi lagu (musikalisasi puisi), drama atau film menjadi novel (novelisasi), atau novel menjadi film (ekranisasi).

Ekranisasi merupkan istilah yang akhir-akhir ini semakin familiar dalam kajian sastra di Indonesia. Ekranisasi adalah pelayarputihan atau pemindahan atau pengangkatan sebuah novel ke dalam film (Eneste, 1991; Damono 2012). Proses ekranisasi tentu akan menimbulkan berbagai perubahan, proses perubahan tersebut misalnya terjadi pada perubahan alat-alat yang dipakai yakni mengubah dunia kata-kata menjadi dunia gambar-gambar yang bergerak secara berkelanjutan.

Film dan novel memiliki kesamaan, yakni berfungsi sebagai media bercerita atau memiliki unsur naratif, yaitu alur, penokohan, latar, suasana, gaya, dan tema/amanat novel yang terdapat pula dalam film sehingga film dan novel dapat dianalisis bersama-sama (Boggs dalam Asrul Sani, 1992). Analisis film dibangun atas unsur-unsur dalam analisis novel.

Film yang diadaptasi dari novel atau karya sastra tentu saja akan mengalami perubahan. Cerita, tokoh, alur, maupun latar bisa mengalami perubahan dari bentuk asli (karya sastra). Apabila novel berbicara melalui bahasa dan kata-kata, film berbicara menggunakan bentuk visual atau gambar. Karya sastra mengajak pembaca berimajinasi secara bebas mengikuti cerita tentang gambaran tokoh, latar, dan suasana dalam cerita. Dalam sebuah karya sastra tidak jarang pengarang berhasil memancing rasa penasaran pembaca dengan permainan kata-katanya. Inilah sebabnya katakata merupakan hal yang sangat penting dalam sebuah karya sastra. Seorang pengarang membangun cerita menggunakan kata-kata yang bisa membawa pembaca dalam cerita dan berimajinasi.

Perihal film yang diadaptasi dari sebuah novel, pada umumnya penonton akan membandingkan antara film dengan novel aslinya. Ketika membandingkan novel dan film, seringkali menimbulkan kekecewaan atau bisa juga kepuasan dalam hati penonton. Perbedaanperbedaan yang terjadi pada novel dan film tentu bukan tanpa alasan. Faktor film yang terkait dengan durasi menyebabkan pekerja film harus kreatif untuk dapat memilih peristiwa-peristiwa yang penting untuk divisualkan. Oleh karena itu, seringkali ditemui adanya pergeseran khususnya berkaitan dengan alur cerita. Dalam tokoh pun terkadang juga ditemukan perubahan. Hal tersebut dilakukan karena antara novel dan film memiliki karakter tersendiri. Penulis berkeinginan untuk mengkaji ekranisasi dari novel Surga Yang Tak Dirindukan karya Asma Nadia menjadi film Surga Yang Tak Dirindukan karya sutradara Kuntz Agus. Film ini merupakan salah satu film hasil adaptasi dari novel yang mendapat penghargaan atas penikmat atau penonton terbanyak di bioskopbioskop Indonesia dengan menembus perolehan 1,5 juta penonton. Film bertema religi ini diproduksi oleh MD Pictures dan disutradarai oleh Kuntz Agus ini diangkat dari sebuah karya sastra novel yang menjadi best seller karya Asma Nadia. Karya sastra yang dihasilkan oleh Asma Nadia banyak menginspirasi banyak orang sehingga mendapat berbagai apresiasi yang luar biasa dari berbagai kalangan. Selain itu, Asma Nadia merupakan penulis novel terkenal di Indonesia yang karyanya banyak sekali diminati oleh masyarakat luas dan banyak mendapat penghargaan atas karyanya. 
Berdasarkan latar belakang tersebut maka penelitian ini dilakukan dengan tujuan untuk mendeskripsikan bentuk ekranisasi novel Surga Yang Tak Dirindukan Karya Asma Nadia menjadi Film Surga Yang Tak Dirindukan Karya Sutradara Kuntz Agus.

\section{METODE PENELITIAN}

Metode yang digunakan dalam penelitian ini adalah metode penelitian deskriptif kualitatif. Sugiyono (2017) mengemukakan bahwa penelitian kualitatif merupakan metode penelitian yang dilakukan pada kondisi alamiah yang berkembang apa adanya, tidak dimanipulasi, dan kehadiran peneliti tidak mempengaruhi perubahan objek tersebut. Metode analisis ini digunakan untuk menelaah isi dari suatu dokumen. Dokumen yang dimaksud adalah novel SurgaYang Tak Dirindukan karya Asma Nadia menjadi film Surga Yang Tak Dirindukankarya sutradara Kuntz Agus.

Teknik pengolahan data dalam penelitian ini meliputi teknik studi pustaka, teknik catat, teknik dokumentasi, dan teknik analisis. Prosedur analisis data pada film Surga Yang Tak Dirindukandalam penelitian ini adalah dengan menggunakan lima langkah: (1) menonton film Surga Yang Tak Dirindukankarya sutradara kuntz agus secara berulang-ulang untuk memahami isi film, (2) menarik functor-functor berdasarkan indikator dalam teori ekranisasi, (3) menganalisis perubahan alur, tokoh, latar dalam novel, dan film Surga Yang Tak Dirindukan kemudian memasukannya dalam aspek pengurangan, penambahan, dan perubahan bervariasi, (4) mendeskripsikan hasil analisis data ekranisasi novel ke dalam film, sehingga tampak perubahannya, dan (5) membuat simpulan dan saran berdasarkan hasil penelitian.

\section{HASIL PENELITIAN DAN PEMBAHASAN}

\section{Bentuk Ekranisasi Novel Surga yang Tak Dirindukan Menjadi Film Surga yang Tak Dirindukan Karya Sutradara Kuntz Agus}

Berdasarkan hasil penelitian, novel Surga Yang Tak Dirindukan karya Asma Nadia mengalami proses ekranisasi dari segi pengurangan, penambahan dan perubahan variasi. Proses ekranisasi tersebut terdapat pada fungsi tokoh, latar, dan alur.

\section{Pengurangan}

\section{a. Pengurangan Tokoh}

Dalam novel Surga Yang Tak Dirindukan terdapat 24 tokoh yang diceritakan, di antaranya Prasetya, Arini, Mei Rose, Ibu Arini, Ayah Arini, A-Ie, Nadia, Adam, Putri, Lulu, Lia, Sita, Amran, Hartono, David, Ray, Mas Putra, Mbak Hani, Ratih, Lolita, Mbak Pur, Mas Yadi, Ina, dan Luki Hidayat. Adapun dalam film Surga Yang Tak Dirindukan terdapat 18 tokoh yang diceritakan, di antaranya Prasetya, Arini, Mei Rose, Nadia, Ayah Arini, Ibu Arini, Amran, Hartono, Lia, Sita, Si Mbok Pembantu Mei Rose, Bibi Pembantu Arini, Ibu Mei Rose, Ibu Prasetya, Ustadz Pengasuh Prasetya, Akbar, Hasbi, dan Pak Richard. 
Tokoh utama dalam novel Surga Yang Tak Dirindukan yaitu Prasetya, Arini, dan Mei Rose karena dari segi cerita, tokoh tersebut merupakan tokoh yang paling banyak diceritakan dan sangat berpengaruh terhadap jalannya cerita. Adapun untuk tokoh tambahan dalam novel yaitu Ibu Arini, Ayah Arini, A-Ie, Nadia, Adam, Putri, Lulu, Lia, Sita, Amran, Hartono, David, Ray, Mas Putra, Mbak Hani, Ratih, Benny, Lolita, Mbak Pur, Bambang, Ina, dan Luki.

Tokoh utama dalam film Surga Yang Tak Dirindukan yaitu Prasetya, Arini, Nadia dan Mei Rose karena dari segi cerita, tokoh tersebut merupakan tokoh yang paling banyak diceritakan. Adapun untuk tokoh tambahan yaitu Ayah Arini, Ibu Arini, Amran, Hartono, Lia, Sita, Si Mbok Pembantu Mei Rose, Bibi Pembantu Arini, Ibu Mei Rose, Ayah Mei Rose, Ibu Prasetya, Ustadz Pengasuh Prasetya, Akbar, Hasbi, dan Pak Richard.

Proses ekranisasi dari novel menjadi film tentunya akan mengalami perubahan salah satunya yaitu pengurangan tokoh. Pengurangan tokoh berarti tokoh yang terdapat di dalam novel tidak dimunculkan dalam film karena beberapa alasan.

Kategori aspek pengurangan tokoh ini dilihat dari tidak ditampilkannya tokoh-tokoh dalam bagian novel tersebut ke dalam film. Berdasarkan hasil penelitian, untuk kategori aspek pengurangan tokoh berjumlah 16 tokoh, yaitu pengurangan tokoh Lulu, Adam, Puteri, A-Ie , Ray, David, Mas Putera, Mbak Hani, Mas Hari, Mbak Pur, Mas Yadi, Mamiek, Lolita, Ratih, Ina, dan Luki Hidayat.

\section{b. Pengurangan Latar}

Aspek pengurangan latar dalam ekranisasi terjadi karena adanya perubahan setelah novel itu di adaptasi ke dalam bentuk film. Pengurangan latar berarti latar yang ditampilkan dalam novel tidak dimunculkan dalam film. Terjadinya pengurangan latar dikarenakan ada beberapa faktor atau alasan oleh pembuat film itu sendiri. Dengan adanya proses pengurangan atau pemotongan maka tidak semua hal yang diungkapkan dalam novel akan dijumpai pula dalam film.

Aspek latar dalam novel Surga yang Tak Dirindukan berjumlah 17 latar, sedangkan dalam film tercatat sebanyak 20 latar. Walaupun jumlah latar dalam film lebih banyak daripada latar yang terdapat dalam novel namun tidak dapat dipungkiri ada latar-latar yang terdapat dalam novel tidak terdapat dalam film. Adapun jumlah latar yang dihilangkan adalah sebanyak 8 latar. Pengurangan latar yang dimaksud antara lain, Teras Masjid Al-Ghifari, Koskosan Blok C-10 Baranang, kampus Arini (IPB), KUA, Kantor Mei Rose, Food Court, Halte dan Gedung Resepsi.

Berdasarkan latar yang terdapat dalam novel dan film, dapat dilihat bahwa dalam ekranisasi novel ke dalam bentuk film juga melakukan ekranisasi pada latar. Dalam visualisasi film, ada beberapa latar yang mengalami pengurangan atau penghilangan. Artinya ada beberapa latar dalam novel yang tidak ditampilkan dalam film. Selain itu terdapat pula penambahan latar yang ditampilkan dalam film dan latar tersebut tidak terdapat dalam novel. 


\section{c. Pengurangan Alur}

Secara keseluruhan, urutan alur dalm novel dan film Surga Yang Tak Dirindukan tidak mengalami perubahan. Urutan alur baik dalam novel maupun film Surga Yang Tak Dirindukan sama-sama menggunakan teknik alur maju, karena dapat ditinjau dari segi penyusunan alur yang sama-sama dimulai dari tahap awal, tahap tengah (konflik dan klimaks), kemudian berakhir pada tahap akhir atau penyelesaian.

Penggambaran alur pada novel Surga Yang Tak Dirindukan terbagi dalam empat bagian yaitu bagian pertama di Masjid Al-Ghifari, bagian kedua di Rumah Sakit, bagian ketiga di rumah Arini, dan bagian keempat di rumah Mei Rose. Adapun penggambaran alur dalam film Surga Yang Tak Dirindukan sedikit mengalami perubahan dari novel aslinya. Film Surga Yang Tak Dirindukanmenceritakan bagian pertama di gang, bagian kedua di Rumah Sakit, bagian ketiga di rumah Mei Rose, dan bagian keempat di stasiun kereta api.

\section{1) Tahap Awal Pertemuan Prasetya dan Mei Rose}

Awal cerita novel Surga Yang Tak Dirindukan dimulai dengan pertemuan Arini dan Prasetya di teras Masjid Al-Ghifari. Keajaiban waktu yang telah mempertemukan keduanya. Prasetya yang masih mengingat Arini karena sempat bertemu ketika masih kecil dulu, karena Prasetya adalah teman Mas Putra kakak Arini. Selanjutnya, Prasetya menyapa Arini sehingga membuat Arini tercengang.

Film tidak memunculkan bagian alur cerita ini karena film memiliki awal pengenalan cerita sendiri. Awal cerita novel ini dirasa memiliki durasi yang panjang karena perkenalan Arini diceritakan secara bertahap. Berbeda dengan film, alur pengenalan yang dibuat lebih dramatis dan perkenalan Arini dan Prasetya pun dihadirkan secara singkat namun menarik.

\section{2) Tahap Tengah Pertemuan Prasetya dan Mei Rose}

Konflik awal atau tahap tengah dalam novel Surga Yang Tak Dirindukan, muncul ketika Prasetya bertemu dengan Mei Rose saat insiden kecelakaan di jalan raya. Kejadian itu berbuntut panjang karena Prasetya memutuskan untuk menolong Mei Rose dan membawanya ke Rumah Sakit. Setelah berbagai peristiwa terjadi di Rumah Sakit akhirnya Prasetya merasa bertanggung jawab untuk selalu menolong Mei Rose, apalagi ketika melihat Mei Rose yang telah melahirkan anak tanpa ayah dan keluarga. Film Surga Yang Tak Dirindukan mengubah atau mengurangi alur yang terlalu panjang dalam novel, sebab film memiliki durasi waktu yang terbatas dan supaya memberikan tontonan yang lebih berksesan bagi penikmat film itu sendiri.

\section{3) Konflik}

Dalam novel, konflik dimulai ketika Mbak Hani yang merupakan bagian keungan di Universitas Prasetya bekerja menelepon Arini. Maksud telepon dari Mbak Hani yaitu untuk bertanya kabar anak-anak dan untuk memberitahukan tagihan pembayaran obat Akbar. Arini merasa heran sebab ketiga anaknya tidak sedang sehat. Lalu Arini menelepon 
nomor yang diberikan Mbak Hani. Arini merasa hatinya sakit ketika ia menelepon nomor tersebut ternyata yang mengangkat teleponnya yaitu istri kedua Prasetya.

Adanya penghilangan atau pengurangan tokoh tidak terlepas dengan adanya pengurangan latar maupun alur. Hilangnya tokoh Mbak Hani di dalam film sebenarnya tidak mengubah alur yang terdapat dalam novel, namun di dalam film dibuat cerita yang berbeda dengan menghadirkan tokoh Si Mbok yang memberitahukan nota pembelian obat Akbar dari saku celana Prasetya.

\section{4) Puncak Konflik}

Novel Surga Yang Tak Dirindukan menunjukkan tahap peningkatan konflik terjadi ketika Arini melihat Prasetya dan Mei Rose berserta Akbar sedang bersama. Tampak di seberang jalan, sosok Prasetya menggandeng seorang anak kecil. Wajahnya terlihat sangat bahagia ketika menepuk pantat si bocah, dan menghalaunya dengan lembut ke dalam mobil. Seorang perempuan tersenyum cerah dan sosok lelaki itu menggenggam tangannya dan saling melempar senyum bahagia. Saat itu juga, perasaan Arini mulai kacau. Arini seperti orang bodoh yang menyaksikan kemesraan suaminya sendiri bersama perempuan lain. Bagian cerita ini berlanjut ketika Prasetya melihat Arini sedang menyaksikan kemesraan Pras dan Mei Rose.

Pada tahap ini terjadi konflik yang berkembang dari tahap sebelumnya. Jika pada tahap sebelumnya Arini masih belum merasakan goncangan atau ketegangan yang luar biasa, pada tahap ini tokoh Arini, Prasetya serta Mei Rose mengalami ketegangan dan kesulitan dalam menghadapi persoalan yang terjadi.

\section{5) Tahap Akhir}

Tahap penyelesaian terhadap semua peristiwa-peristiwa dalam novel Surga Yang Tak Dirindukan muncul setelah melewati berbagai macam konflik. Selama perjalanan kehidupan rumah tangga mereka, Pras, Mei Rose dan Arini seolah-olah berada di samudera pikirannya masing-masing. Berbagai macam peristiwa pahit yang menghampiri Arini dan Mei Rose, serta Pras yang dihadapkan dengan keadaan yang sangat bersalah membuat ketiganya sama-sama merasakan luka yang sama.

Pada tahap ini terjadi penyelesaian dari berbagai macam konflik yang terjadi. Akhir penyelesain konflik pada novel memang tidak digambarkan secara jelas. Namun, ketika Arini menemui Mei Rose di rumahnya, terdapat penyelesaian konflik yang menggantung di antara mereka bertiga.

\section{Penambahan}

\section{a. Penambahan Tokoh}

Aspek penambahan tokoh merupakan penambahan tokoh dalam film, artinya ada penambahan beberapa tokoh dalam film yang tidak terdapat dalam novel. Penambahan tokoh bisa terjadi karena sutradara memiliki anggapan bahwa tokoh tertentu yang terdapat dalam 
film dirasa penting. Dalam film Surga Yang Tak Dirindukan terdapat beberapa tokoh yang tidak dimunculkan dalam novel.

Kategori aspek penambahan tokoh ini dilihat dari munculnya tokoh-tokoh dalam film dan tokoh tersebut tidak terdapat dalam novel. Berdasarkan hasil penelitian, untuk kategori aspek penambahan tokoh berjumlah 6 tokoh, yaitu penambahan tokoh Prasetya kecil, ayah angkat Prasetya, Hasbi, asisten rumah tangga Arini, Pak Richard, dan asisten rumah tangga Mei Rose.

\section{b. Penambahan Latar}

Berdasarkan hasil penelitian, untuk kategori aspek penambahan latar berjumlah 9 latar, yaitu penambahan latar Gang, Jalan Raya, Taman Kanak-kanak, Pantai, Apotik, Kaffe, Gedung Pementasan, Jembatan Tugu Yogyakarta, dan Stasiun Kereta Api. Kategori aspek penambahan latar ini dilihat dari munculnya latar dalam film dan latar tersebut tidak terdapat dalam novel. Penambahan latar bisa terjadi karena sutradara ingin menampilkan cerita yang lebih dramatis dan berbeda dari cerita aslinya.

\section{c. Penambahan Alur}

Secara keseluruhan, urutan alur dalm novel dan film Surga Yang Tak Dirindukan tidak mengalami perubahan. Urutan alur baik dalam novel maupun film Surga Yang Tak Dirindukan sama-sama menggunakan teknik alur maju, karena dapat ditinjau dari segi penyusunan alur yang sama-sama dimulai dari tahap awal, tahap tengah (konflik dan klimaks), kemudian berakhir pada tahap akhir atau penyelesaian.

\section{1)Tahap Awal Terdapat Penambahan Alur Pras Kecil Melihat Ibunya Bunuh Diri}

Awal cerita film dimulai dengan adegan yang tampak berlatar waktu tahun 1980an, dilihat dari pakaian dan kendaraannya. Adegan tersebut merupakan kilas balik yaitu mimpi dari seorang pria yang kemudian diketahui bernama Prasetya. Adegan itu menggambarkan saat Prasetya kecil melihat dengan mata kepala sendiri ibunya bunuh diri dengan menabrakkan diri ke mobil yang tengah melaju di jalan depan gang rumah mereka.

Film Surga Yang Tak Dirindukan menggambarkan tahap pengenalan yaitu ketika Prasetya yang masih kecil melihat ibunya bunuh diri di depan sebuah gang. Alur cerita dalam film ini berbeda dengan novel. Jika novel memulai awal cerita dengan pertemuan antara Arini dan Prasetya, dalam film membuat awal cerita yang lebih dramatis yaitu seperti yang telah dipaparkan di atas.

\section{2)Tahap Tengah Terdapat Penambahan Alur Perdebatan Pras, Hartono, dan Amran}

Tahap tengah pada film menunjukkan adanya penambahan alur yang tidak dimunculkan dalam novel yaitu penambahan alur ketika Pras, Amran dan Hartono berdebat mengenai pernikahan Mei Rose dan Prasetya. Konflik awal muncul ketika Prasetya telah menikah dengan Mei Rose lalu muncul konflik perdebatan antara Pras, Amran dan Hartono. Hartono yang menentang keputusan Pras yang telah menikahi Mei Rose memberikan pendapat agar Pras menceraikan Mei Rose dan menganggap semuanya tidak pernah terjadi. 
Pras yang memiliki rasa tanggungjawab terhadap Mei Rose enggan mengikuti saran Hartono tersebut. Namun, keputusan Pras menikahi Mei Rose ternyata berbuntut panjang dan memberikan dampak bagi kehidupan Pras, dampak bagi pernikahannya dengan Arini dan bagi proyeknya di Kulon Progo.

\section{3)Konflik}

Berdasarkan hasil penelitian, terdapat penambahan alur berupa konflik yang tidak dimunculkan dalam novel yaitu penambahan alur ketika Pras, Amran dan Hartono berdebat mengenai pernikahan Mei Rose dan Prasetya. Hartono yang menentang pernikahan Prasetya dan Mei Rose menyuruh Pras untuk menceraikan Mei Rose karena merasa kasihan kepada Arini.

\section{4)Puncak Konflik}

Berdasarkan hasil penelitian, terdapat penambahan alur berupa puncak konflik yang tidak dimunculkan dalam novel yaitu penambahan alur yang terjadi ketika Pras, Amran dan Hartono mendapat teguran dari klien menegnai proyek Kuulon Progo. Hartono yang sejak awal menduga akan terjadi masalah, akhirnya marah kepada Amran dan Prasetya.

\section{5)Tahap Akhir}

Berdasarkan hasil penelitian, terdapat penambahan alur pada tahap akhir yang tidak dimunculkan dalam novel yaitu penambahan alur yang terjadi ketika Pras, Amran, dan Hartono bertemu dengan klien untuk menyelesaikan masalah mengenai proyek Kulon Progo yang telah terbengkalai. Setelah pertemuan terjadi, akhirnya masalah proyek Kulon Progo dapat teratasi.

\section{Perubahan Variasi}

\section{a. Perubahan Variasi Karakter Tokoh}

Perubahan variasi pada tokoh berarti terjadi perubahan pada karakter tokoh yang berada dalam film. Terjadinya perubahan variasi pada tokoh dipengaruhi oleh beberapa faktor, antara lain media yang digunakan, persoalan penonton, dan durasi waktu pemutaran.

Kategori aspek perubahan bervariasi dilihat dari adanya perubahan penggambaran tokoh dalam film. Berdasarkan hasil penelitian, untuk kategori aspek perubahan bervariasi berjumlah 3 tokoh, yaitu perubahan variasi pada karakter tokoh Arini, Prasetya, dan Mei Rose.

\section{b. Perubahan Variasi Latar}

Aspek perubahan variasi latar merupakan perubahan variasi pada latar dalam film, artinya ada perubahan yang terjadi pada latar mengenai cerita yang terjadi dalam film yang tidak digambarkan dalam novel. Perubahan variasi pada latar bisa terjadi karena sutradara memiliki anggapan bahwa dengan adanya perubahan variasi, maka cerita pada latar tersebut akan semakin kuat, dramatis dan menarik bagi penonton. Dalam film Surga Yang Tak Dirindukan terdapat beberapa perubahan variasi pada latar yang tidak dimunculkan dalam 
novel, yaitu perubahan variasi pada latar rumah sakit, rumah Mei Rose, rumah Arini dan Pasetya.

\section{c. Perubahan Variasi Alur}

Aspek perubahan variasi alur merupakan perubahan variasi yang terjadi pada alur dalam film, artinya ada perubahan yang terjadi pada bagian alur dalam film yang tidak digambarkan dalam novel. Perubahan variasi pada alur bisa terjadi karena sutradara memiliki anggapan bahwa dengan adanya perubahan variasi, maka cerita yang ditampilkan akan lebih dramatis dan sesuai dengan durasi waktu. Dalam film Surga Yang Tak Dirindukan terdapat beberapa perubahan variasi pada alur yang tidak dimunculkan dalam novel.

\section{1) Tahap Awal Terdapat Perubahan Alur Pertemuan Arini dan Prasetya}

Terdapat perubahan alur ketika Pras bertemu dengan Arini di Taman Kanakkanak. Dalam film Surga Yang Tak Dirindukan, tahap pengenalan yang dimulai yaitu ketika Prasetya datang ke Taman Kanak-kanak untuk mengantarkan Hasbi yang telah terjatuh dari sepeda. Ketika Prasetya sampai di Taman Kanak-kanak, Prasetya terpesona dengan kecantikan ibu guru yang sedang menyampaikan dongeng Madaniah. Dia adalah Arini. Disini lah pertemuan pertama Prasetya dan Arini.

\section{2) Tahap Tengah Terdapat Perubahan Pertemuan Prasetya dengan Mei Rose}

Terdapat perubahan alur ketika Pras menikahi Mei Rose di rumah sakit. Pertemuan Prasetya dan Mei Rose ini menjadi tahap awal munculnya konflik. Pada film Surga Yang Tak Dirindukan, konflik awal muncul ketika Prasetya telah menikahi Mei Rose. Konflik ini diawali adegan ketika Mei Rose yang berniat untuk bunuh diri. Prasetya yang tidak ingin masa lalunya terulang kembali ketika melihat ibunya bunuh diri, berusaha menolong Mei Rose. Mei Rose yang sangat putus asa tetap bersikeras untuk mengakhiri hidupnya, sampai akhirnya Mei Rose luluh karena Prasetya berjanji akan menikahinya. Hal ini menjadi konflik bagi kehidupan Prasetya terutama bagi rumah tangganya dengan Arini.

\section{3) Konflik}

Terdapat perubahan alur berupa konflik yaitu ketika Arini menerima telepon untuk pembayaran sebuah obat. Novel menceritakan bahwa Arini mengetahui Prasetya membayar obat untuk Akbar dari Mbak Hani bagian keuangan di Universitas Prasetya mengajar. Berbeda dengan film yang menceritakan bahwa Arini mengetahui pembayaran obat untuk Akbar yaitu dari asisten rumah tangga Arini.

\section{4) Puncak Konflik}

Terdapat perubahan alur yang terjadi ketika Arini melabrak Mei Rose. Selain itu, puncak konflik juga terjadi ketika Arini mengusir Prasetya dari rumah karena telah mengetahui Pras yang telah berpoligami.

Film Surga Yang Tak Dirindukan memunculkan tahap peningkatan konflik terjadi ketika Arini melabrak Mei Rose di rumahnya. Mei Rose langsung memberitahu Prasetya perihal kedatangan Arini, Mei Rose merasa khawatir dengan hubungan Arini dan Prasetya setelah mengetahui semuanya. Prasetya yang sedang melaksanakan meeting di kantor 
langsung bergegas ke rumah Arini untuk menjelaskan semuanya. Namun, Arini telah mengetahui semuanya dan menganggap Prasetya telah berkhianat. Arini yang sedang kacau dan dilanda emosi karena kesedihannya akhirnya mengusir Prasetya dari rumah mereka.

\section{5) Tahap Akhir}

Tahap penyelesaian terhadap semua peristiwa-peristiwa dalam novel Surga Yang Tak Dirindukan muncul setelah melewati berbagai macam konflik. Selama perjalanan kehidupan rumah tangga mereka, Pras, Mei Rose dan Arini seolah-olah berada di samudera pikirannya masing-masing. Berbagai macam peristiwa pahit yang menghampiri Arini dan Mei Rose, serta Pras yang dihadapkan dengan keadaan yang sangat bersalah membuat ketiganya sama-sama merasakan luka yang sama.

Terdapat perubahan alur pada tahap akhir yang diubah dari novel aslinya yaitu perubahan alur yang terjadi ketika Arini yang telah menerima dengan ikhlas semua kejadian pahit yang menimpa rumah tannganya. Selain itu, Mei Rose yang telah memilih untuk pergi dari kehidupan Prasetya dan Arini.

Secara garis besar perubahan bentuk ekranisasi novel ke dalam film bukan hanya mempengaruhi pada media kata-kata atau bahasa yang diubah ke dalam bentuk gambar atau audio visual saja. Namun, pada kenyataannya sebelum melakukan perubahan lewat gambar-gambar yang dimunculkan dalam sebuah film, seorang sutradara akan melakukan penulisan naskah atau skenario terlebih dahulu sebagai acuan dasar dalam proses pembuatan film. Skenario yang dibuat tentunya berdasarkan cerita yang tertuang di dalam novel jika film itu hasil adaptasi dari sebuah novel. Tentu saja ketika membuat skenario cerita-cerita yang di dalam novel sedikit banyaknya akan mengalami proses ekranisasi atau perubahan seperti pengurangan, penambahan, dan perubahan variasi. Perubahan tersebut meliputi aspek tokoh, latar serta alur. Hal ini bisa terjadi karena durasi yang tersedia untuk membuat sebuah film sangat terbatas, sehingga baik tokoh latar maupun alur yang tertuang di dalam novel akan disesuaikan kembali dengan film yang akan diproduksi. Meskipun novel tersebut mengalami perubahan ketika di adaptasi ke dalam sebuah film, tema yang dimunculkan tidaklah berubah, dan keseluruhan gambaran cerita masih bisa dirasakan oleh penikmat film.

\section{PENUTUP}

Novel Surga yang Tak Dirindukan karya Asma Nadia mengalami proses ekranisasi dari segi pengurangan, penambahan, dan perubahan variasi. Proses ekranisasi tersebut terdapat pada fungsi tokoh, latar, dan alur.

1. Proses ekranisasi pada kategori aspek pengurangan, terdapat pengurangan 16 tokoh, 8 latar, dan 5 bagian alur. Pengurangan tokoh, latar serta alur pada novel yang dilakukan dalam visualisainya ke dalam bentuk film secara keseluruhan masih wajar dilakukan. 
2. Proses ekranisasi pada kategori aspek penambahan, terdapat penambahan 6 tokoh, 9 latar, dan 5 bagian alur. Penambahan tokoh, latar serta alur pada novel yang dilakukan dalam visualisainya ke dalam bentuk film secara keseluruhan masih relevan dengan cerita yang ada dalam novel.

3. Proses ekranisasi pada kategori aspek perubahan variasi, terdapat perubahan variasi 3 tokoh, 3 latar, dan 5 bagian alur. Perubahan variasi tokoh, latar serta alur pada novel yang dilakukan dalam visualisainya ke dalam bentuk film secara keseluruhan masih relevan dengan cerita yang ada dalam novel. Selain itu, perubahan variasi yang dilakukan pada film Surga Yang Tak Dirindukan tidak jauh berbeda dengan novel. 


\section{DAFTAR PUSTAKA}

Damono, S. D. (2012). Alih Wahana. Jakarta: Editum.

Eneste, P. (1991). Novel dan Film. Flores: Nusa Indah.

Nadia, A. (2015). Surga yang Tak Dirindukan. Depok: AsmaNadia PublishingHouse.

Nurgiyantoro, B. (2015). Teori PengkajianFiksi. Yogyakarta: Gajah Mada University Press.

Sani, A.(1991). Transformasi Novel ke dalam Film. Jakarta: IKIP Jakarta.

Sugiyono. (2017). Metode Penelitian Kuantitatif, Kualitatif, dan R\&D. Bandung: Alfabeta.

Sumarno, M. (1996). Dasar-Dasar Apresiasi Film. Jakarta: PT. Grasindo. 